\title{
China's port price regulation effect on the efficiency of the port
}

\author{
GuoShiZhuo \\ line1:Shanghai Maritime University,College of Economics and management ,Pudong,Shanghai \\ line3:Shanghai,China \\ Line4:zhuoforever@126.com
}

\begin{abstract}
Port as an important part of national infrastructure, the country's economy is of great strategic significance. For a long time, given the size of the port economy and regional monopoly characteristics, Chinese ports has been under strict government regulation. However, as the worldwide since 1970 $s$ the rise of the tide of deregulation in natural monopoly industries, according to port price regulation reform in our country also more and more attention. This article simply analyses the development course and existing problems of China port price regulation, and put forward the key point of China port price regulation is points area and business reform and upper and lower price, and introduce the super efficiency DEA model to evaluate the efficiency of port enterprises, and then determine the efficiency of the port enterprise factor, thus price regulation reform for the future of Chinese ports have certain guiding significance.
\end{abstract}

Keywords- Chinese ports, the price regulation, port efficiency

\section{INTRODUCTION}

Along with the development of market economy, the port enterprises in our country the price regulation of our government reform seriously lags behind the requirements of the development of the market, and port enterprise income is closely related to foreign trade stray stevedoring tariff handling charges, foreign trade container main LaoWuXing fee charge standards such as more than 10 years, which have not been adjusted (port of foreign trade goods still performed on December 24, 2001 issued by the ministry of transportation fee charge standards). As the price index and the large increase in enterprise cost most of the port enterprise management difficult, port price management system needs to be improved.

Compared with other monopoly industries, the study of the theory of the port price regulation in our country is still lagging behind, the port of the specific content of price regulation, the core issues in building the incentive price regulation model system of research results has been observed. Therefore port price regulation research has become the urgent needs to solve in our country's current port development of one of the major issues.

Three kinds of port charge are shown in table 1.

\begin{tabular}{|l|l|l|}
\hline shipping cost & the cost of goods & Other fees \\
\hline $\begin{array}{l}\text { Vessel tonnage } \\
\text { dues; }\end{array}$ & Cargo port charge; & Ship repair; \\
Handling charge; fhe port & Dunnage \\
Handling fee; & materials fee; \\
charges; & storagecharge; & The crew cash \\
Ship pilotage ; & Transfer fees; & advance \\
lighthouse fee; & Tally fee; & fee,etc. \\
\hline
\end{tabular}

\begin{tabular}{|l|l|l|}
\hline Tug fee ; & goods inspection & \\
Berthing fee ; & fee,etc. & \\
Quarantine & & \\
fee,etc. & & \\
\hline
\end{tabular}

\section{THE NECESSITY OF PRICE CAP REGULATION}

As customers choose other port group is very high, the cost of the port area of monopoly is still evident, it also makes if to completely let go port charges will there is a problem, as a regional port enterprises take advantage of its regional monopoly combined to raise prices to obtain monopoly profits. Even for a port to relax economic regulation and introducing competition, its market structure will still showed high concentration, then competition strength is insufficient, so need government regulation play a role. Because of the industry characteristics, normally even if the port is competitive, and only two to three direct competitors. So according to the standard method to measure market share and concentration would be higher. In most cases, the high market concentration means likely anticompetitive behavior. Such as fewer competitors could trigger price collusion, distribution, customers, or geographic region, establish cartel, etc.

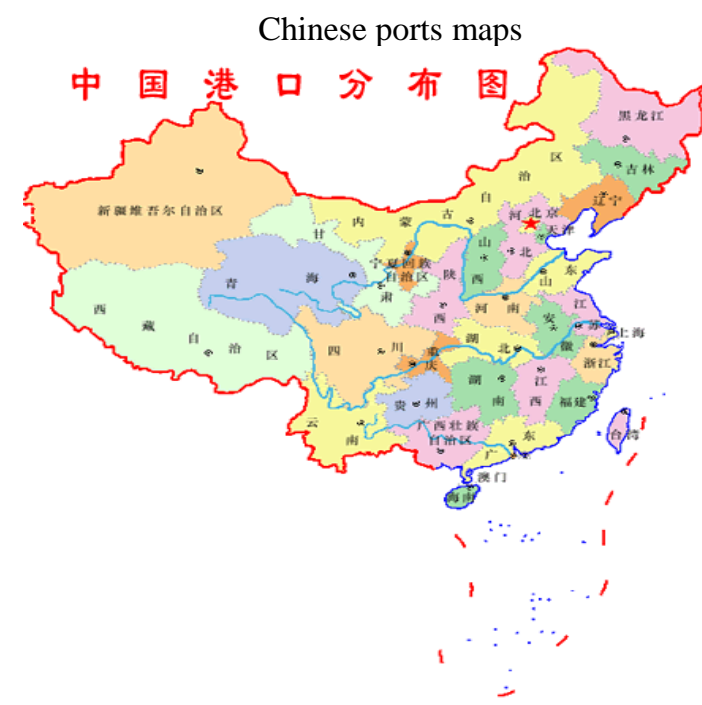

In the absence of economic regulation, a leading or monopoly port enterprises will adopt anti-competitive practices, including the price discrimination, exclusive deals, increase the cost of competitors, etc. In order to prevent these problems, adopting the importance of price cap regulation 
arises at the historic moment. Price cap regulation can protect the interests of consumers, prevent has the dominant position of enterprises disorderly price, enroach on consumer interests. Cap regulation will give enterprises greater pricing power, in this way, enterprise can according to the market demand to set up the more flexible price strategy. Therefore, on the basis of investigating the port enterprise production cost comprehensively advancing specifications cap regulation system, is the best path of port regulation reform in China.

\section{THE NECESSITY OF THE PRICE FLOOR REGULATION}

Cap regulation lies in the promotion and incentives, and the lower limit of the embodiment of the regulation is more of market intervention. Due to the distance between the ports in the same port group is more and more small, the construction of new port, port scale enlargement, the improvement of transportation condition, make the cross between port hinterland is more and more big, the competitive strengthen constantly. Absorbs the domestic trade price of bulk cargo loading and unloading port enterprise after let go of the experiences and lessons of price war against price competition development to a certain degree, the government should take certain measures and regulations at the same time, through the implementation of the price floor regulation to prevent vicious competition.

Therefore, we can not completely copy the developed countries such as price cap regulation method. In view of the long-term and stable development of port industry, on port regulation, should consider the price floor regulation at the same time. The price floor regulation refers to the government for certain industries the lower limit of the price of a product or service changes to regulations, and banned companies any lower price. The price floor regulation form is unitary, mainly is specified for the relevant product or service during the period the absolute minimum price. To sum up, the lower limit on the price regulation of combining the comprehensive regulation time to mature. Should have a price ceiling to prevent several port of conspiring to violate consumer interest, also want to have a price floor, can't let companies within the same port group is lower than the cost to compete on price, prevent loss of state-owned assets. Within the scope of reasonable price controls let companies have a wider range of independent pricing power, let the enterprise rely on service, rely on business to compete.

\section{DEA MODEL BASED ON DATA ANALYSIS PRICE IMPACT ON THE EFFICIENCY OF CHINESE PORTS}

To be sure, this part of the price regulation of object mainly is the port of loading and unloading operations. In the design of our country port price cap regulation model, considering the situation of our country is different and the port enterprise production and business operation characteristics, and thus can not completely copy the RPI - X model. Combines the actual conditions of our country, this paper builds the price regulation of our country's port adjustment model is as follows:
$\mathrm{Pt}+1=\mathrm{Pt}(1+\mathrm{I}-\mathrm{X})+\mathrm{Z}(1-1)$

Type 1-1:

$\mathrm{Pt}+1$-price cap regulation of the current period;

Pt - a price cap regulation period;

I - changes in the port enterprise cost;

$\mathrm{X}$ - port enterprise efficiency factor;

$\mathrm{Z}$ - adjustment factor unknowns.

Price cap regulation model is essentially regulation price rise or fall of the rate, it is a reasonable price for assumptions, and the determination of basic price must based on the cost, this determines the price cap regulation model in constructing in our country cannot avoid the cost problem. Initial pricing models of price regulation are as follows:

$\mathrm{P} 0=\mathrm{C}+\mathrm{R}+\mathrm{T}(1-2)$

Type 1-2:

C - the unit cost of production and operation;

$\mathrm{R}$ - the unit profit;

$\mathrm{T}$ - legal and tax.

Because port is capital intensive and labor intensive industry, therefore total assets, net value of fixed assets, number of employees, main business cost four input indexes both from material, capital and manpower three perspective considers the ports listed company, also embodies the main cost of its core business, to reflect the actual situation of the port listed companies and the basic characteristics. Measure the output of port enterprise is the most important indicator of cargo throughput, and as one of the enterprises, especially listed companies, profit is the first priority, so this article select net profit at the same time, main business profit as the output indexes.

Table 2 Evaluation of the efficiency of the port input and output indicators

\begin{tabular}{|l|c|}
\hline input indicators; & Output indicators \\
\hline Total assets & Cargo throughput \\
\hline Net value of fixed assets & Net profit \\
\hline Main business costs & Main business profit \\
\hline Number of employees & labor cost \\
\hline
\end{tabular}

At home and abroad Investigations of the price cap regulation model very much, but mostly just stay at the levels of theoretical research, lack of maneuverability, the reason is that avoid the implementation of the core and key of price cap regulation factor $\mathrm{X}$ - efficiency calculation. This paper discusses the core issues, the price is according to the literature of the DEA results cost impact on the efficiency of the port. 


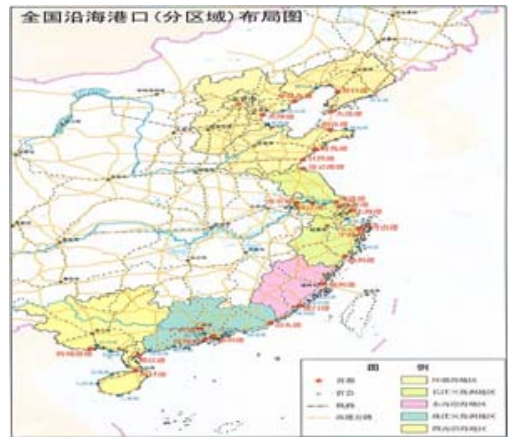

Companies, in general, the lower the efficiency, the values of $\mathrm{X}$ is larger; On the other hand, business efficiency is higher, the smaller values of $X$. At the same time to determine the values of $\mathrm{X}$ should make the company can maintain appropriate profits to expand equipment, pay interest, at the same time to motivate the improvement of efficiency, reduce the cost.

The price floor regulation can prevent the occurrence of irrational cutthroat competition, encourage enterprises more competitive through technology, business and service innovation. At the same time, due to the enterprise to obtain the benefits of technology innovation, which would help to promote the efficiency of enterprises, which is beneficial to enhance enterprise competitiveness. Lower limit of the standard can be according to actual cost of the port enterprise, its value can be obtained from the company's annual report.

\section{CHINESE 10 PORT THROUGHPUT RANKING IN 2011}

First: Ningbo - Zhoushan Port, 691 million tons

Ningbo Zhoushan Port is located on the northeast coast of Zhejiang Province, the Minato involving Ningbo and Zhoushan City. January 1, 2006, Ningbo Port and Zhoushan Port formal merger. The port is in very good condition, dotted with islands of the Zhoushan Islands, the natural barrier of the port. Port main distribution in Ningbo Zhenhai, Beilun coast, and Zhoushan Island south coast. Large international ocean-going vessels the deepwater channel Xiashimen and out. Port has become the container ocean Route Port, the largest ore transit base, the largest crude oil transshipment base, the largest domestic coastal liquid chemical storage base, and the East China major coal transport base.

Second: Shanghai Port, 620 million tons

Shanghai Port is located in the leading edge of the Yangtze River Delta, home the central mainland coastline of $18,000 \mathrm{~km}$, recapped the Yangtze River estuary,Located in the Yangtze things transportation channel offshore north-south transport corridor intersection of China's coastal hub port,China's opening up to participate in the important port of the international economic cycle. Shanghai 99\% of the foreign trade goods entering and leaving via Shanghai Port, completed a year of foreign trade throughput accounted for about $20 \%$ of the nation's coastal port.

Third: Tianjin Port, 451 million tons

Tianjin Port is located in the Bohai Bay, on the estuary of Haihe River, at the intersection point of the Beijing-Tianjin city belt and the Bohai Economic Circle, Bohai Sea ports in the north, northwest and inland areas such as the shortest distance from the port, is the capital of Beijing and Tianjin, the gateway to the sea, is the eastern end of the starting point of the Eurasian Continental Bridge. references

[1] G.J.Stigler, C.Friedland.What Can the Regulators Regulate: The Case of Electricity[J]. Journal of Law and Economics, 1962: 34-37.

[2] .Laffont, J.Tirole, Creating Competition through Interconnection: Theory and Practice[J]. Journal of Regulatory Economics, 1996, 29:227-256.

[3] [Tongzon,J. Efficiency Measurement of Selected Australian and Other International Ports Using Data Envelopment Analysis. Transportation Research Part A: Policy and Practice, 2001, 35(2), 113-128.

[4] Wang Dongmei, Huang Lin, Wang Jinrong . Magic Square Transformation Encrypted Digital Hologram [J]. Journal of Zhejiang University of Technology. 2007, (01)

[5] Zhang Lianjun. Analysis of Image Chaotic Encryption Technology [J]. Modern Intelligence. 2005, (08)

[6] Development Status [J]. Computer Security. 2002, $2: 11 \sim 15$

[7] Zhao Jin, Fang Jinqing. Research Progress in the Application of Modern Information Security and Chaotic Secure Communication [J]. Progress in Physics. 2011,22 25 